\title{
A Multi-Dimensional Approach to Revealing Causes of Pavement Failures: Case Study of Minna - Suleja Highway, North-Central Nigeria
}

\author{
Umar Muhammed Umar ${ }^{1, ~ *, ~ E j e p u ~ J u d e ~ S t e v e n ~}{ }^{2}$, Aweda Abdulwahid Kolawale ${ }^{1}$, \\ Ozoji Tochukwu Malachi ${ }^{1}$, Adamu Lukman Musa ${ }^{3, *}$, Abdulkadir Sani Ahmad, \\ Umoru Charles Ile ${ }^{4}$ \\ ${ }^{1}$ Department of Geology and Mining, Faculty of Applied Sciences and Technology, Ibrahim Badamasi Babangida University, Lapai, Nigeria \\ ${ }^{2}$ Department of Geology, School of Physical Sciences, Federal University of Technology, Minna, Nigeria \\ ${ }^{3}$ Department of Earth Sciences, Faculty of Natural Sciences, Kogi State University, Anyigba, Nigeria \\ ${ }^{4}$ Department of Strategic Space Application, National Space Research and Development Agency, Abuja, Nigeria
}

Email address:

ummar@ibbu.edu.ng (U. M. Umar), lukman10musa@yahoo.com (A. L. Musa)

${ }^{*}$ Corresponding author

\section{To cite this article:}

Umar Muhammed Umar, Ejepu Jude Steven, Aweda Abdulwahid Kolawale, Ozoji Tochukwu Malachy, Adamu Lukman Musa, Abdulkadir Sani Ahmad, Umoru Charlse Ile. A Multi-Dimensional Approach to Revealing Causes of Pavement Failures: Case Study of Minna - Suleja Highway, North-Central Nigeria. American Journal of Water Science and Engineering. Vol. 6, No. 3, 2020, pp. 81-88.

doi: 10.11648/j.ajwse.20200603.11

Received: July 27, 2020; Accepted: August 8, 2020; Published: August 20, 2020

\begin{abstract}
Remote sensing, geotechnical studies and geophysical data have been applied to determine the causes of the continuous pavement failure of the Minna - Suleja highway in a part of North-Central Nigeria. In this study, remotely sensed data in the form of Landsat 8 OLI and SRTM DEM were processed to extract structural lineaments and drainage pattern of the area. Geotechnical evaluation of soil samples such as grain size analyses, Compaction Test, Atterberg Limits and California Bearing Ratio (CBR) determination were also conducted. Geophysical data acquired were in the form of lateral resistivity profiling data at $500 \mathrm{~m}$ intervals and twenty-one Vertical Electrical Sounding (VES) spread across the selected sections of the road. Lineament analysis revealed predominant NNE-SSW trending structures. A notable percentage of the Lineaments trend NW- SE. Both sets of lineaments constitute a conjugate fracture system. CBR values in both portions range from $5-15 \%$ in soaked condition and unsoaked condition at OMC. Plasticity index range from $14-30$ and $19-45$ in both portions. Quantitative interpretation of the VES results established the presence of mostly three geologic layers which are: Clayey top soil, sand/lateritic sand and weathered basement. Resistivity values range from $20 \Omega \mathrm{m}$ to $300 \Omega \mathrm{m}$ for the top soil layer. The depths of this layer were generally less than $3 \mathrm{~m}$. Preponderance of intersections of lineaments along failed portions account for near surface fractures, making these zones weak. This can be linked to low resistivity of the near surface materials and shallowness of the water bearing zones especially on the failed portions on which the road pavement foundation was laid. A distinction could not be made on the results of the geotechnical properties in both the failed and stable portions of the road. Hence, failure factors are not linked to the geotechnical properties of the soils.
\end{abstract}

Keywords: Remote Sensing, Lineaments, Geophysics, Geotechnical Investigation, Pavement Failure

\section{Introduction}

With increasing civilisation, it has become the norm for people to move from one place to another using various means of communication. Urbanisation is one of the chief factors that contribute to increasing road usage. Vehicular transportation is one of the commonest means by which goods and services are transported and rendered. Because of its significant role in achieving national economic development and contribute to the overall performance and 
social functioning of the community, the quality of a country's road network should be constructed in an efficient way in order to maximize economic and social benefits [1]. Several factors have been alluded to deterioration or roads. These include road usage, inadequate supervision, poor construction materials, non-compliance to specifications/design problems, inadequate knowledge of the characteristics and more importantly, the behaviour of residual soils on which the roads are constructed [2]. Non incorporation of geological studies during design and construction of roads have been identified to be the major factor causing incessant road failure in Nigeria [3, 4]. Geological factors such as the nature of topsoil (subgrade) and the near surface geologic sequence, existing geological structures such as fractures and faults and hydrogeology of that area can impair stability of any road structure. Hence, it is imperative that these factors are properly investigated prior to any road construction. Therefore, this research was conceptualised to investigate the causes of the continuous pavement failure of the Minna - Suleja highway in a part of North-Central Nigeria using Remote sensing, geotechnical studies and geophysical data.

This work is aimed at determining the nature of soils and the near-surface geologic sequence that characterize the road segment and identify the presence of geologic structures that has probably made the road vulnerable to failure after construction, the geotechnical properties of the subsurface geologic materials soil and their implications on the stability of the road using geologic, ground based structural mapping, extract lineaments, conduct ground resistivity survey utilising
VES at selected sites using Schlumberger configuration $(\mathrm{AB} / 2=50 \mathrm{~m})$ and correlate results from all methods applied in the study and infer the implication to road failures.

\section{Study Area}

The area of study form part of the south-western portion of Minna Sheet 164 which falls within Chanchaga Local Government Area of Niger State, north-central Nigeria. The area is delimited within Latitudes $9^{\circ} 32^{\prime} 00^{\prime \prime} \mathrm{N}$ and $9^{\circ} 34^{\prime} 00^{\prime \prime}$ $\mathrm{N}$ and Longitudes $6^{\circ} 34^{\prime} 00^{\prime \prime} \mathrm{E}$ and $6^{\circ} 34^{\prime} 00^{\prime \prime} \mathrm{E}$. with a total area of about $14 \mathrm{~km}^{2}$ covered (Figure 1). Geologically, the area consist of rocks of the Basement Complex category of the Nigerian geology. Lithologically, the area is made up of the Granite, Quartzite, Schist and Gneiss with insignificant alluvial deposits. The area has a dentritic drainage configuration with River Gurara as the major River that drain the area which is characterized by tributaries of rivers Kudan, Jatau, Gudna, Jedna and Jednadalaso which are lithologically and structurally controlled [5]. Annual rainfall of the study area averages about 1300 and stretches from the month of April to October. The peak of rainfall is recorded between the months of August and September. The maximum day time temperature is about $35^{\circ} \mathrm{C}$ in the months of March and April, while a minimum temperature of about $24^{\circ} \mathrm{C}$ is recorded in the months of December and January.

The maximum day time temperature is about $35^{\circ} \mathrm{C}$ in the months of March and April, while a minimum temperature of about $24^{\circ} \mathrm{C}$ is recorded in the months of December and January [6].

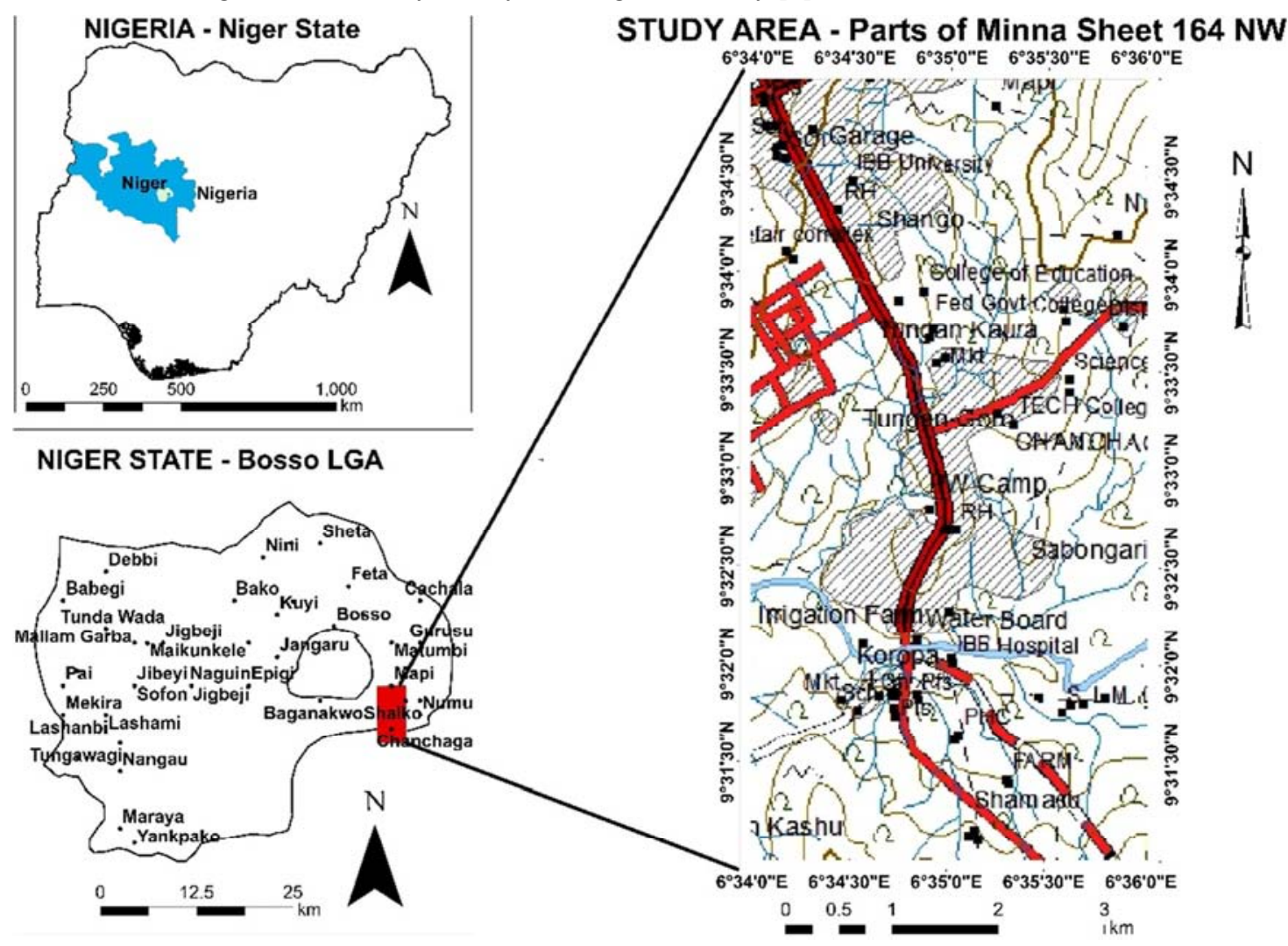

Figure 1. Location map of the study area. 


\section{Method of Study}

Lithological and structural field mapping was carried out on a scale of 1:12,500 where joints and fractures orientations (azimuthal reading) were taken where possible. Hydrogeological conditions of the area was determined by observing the conditions of some selected hand dug wells. Factors such as topography, geographic location, weathering, rock type and structure were considered. Rose diagram showing the predominant joint directions were constructed from these measurements.

\subsection{Remote Sensing/Lineament Analysis}

A combined version of 5.3 Exelis visual information solutions and ArcGIS softwares (Boulder CO USA and Environmental Systems Research institute CA, USA respectively) were used to perform image processing for both Landsat OLI and SRTM DEM. SRTM shaded relief representations were achieved using sun elevation angle of $25^{\circ}$ and $0^{\circ}, 45^{\circ}, 90^{\circ}, 270^{\circ}$ and $135^{\circ}$ sun illuminations directions, which was oriented perpendicularly to the prominent structural directions. This was done in selected regions so as to enhance the linear structures. Directional and normalised derivatives were also calculated to accentuate near surface structures from which lineaments were identified and delineated. Using ArcGIS software, lineaments were digitized separately from SRTM DEM and Landsat maps and subsequently combined to form a composite of lineaments extracted from remote sensing imagery. These were achieved using the methods of [7-11].

\subsection{Electrical Resistivity Survey}

The electrical resistivity survey in the form of the Vertical Electrical Sounding was acquired using Schlumberger array. A total of twenty-one (21) stations were occupied across the study area at an inter-station distance of $100 \mathrm{~m}$ (Figure 2). The maximum $\mathrm{AB} / 2$ electrode spacing was pegged at $200 \mathrm{~m}$. A locally fabricated but calibrated Resistivity meter was used to acquire the data. The resistivity data was presented as field curves (by plotting the apparent resistivity (qa) against $\mathrm{AB} / 2$ or half the spread length on a bi-logarithmic paper. The data was interpreted qualitatively by visual inspection to obtain initial estimates of resistivity and thickness of the various geoelectric layers at each VES location. These geoelectric parameters were used as starting model for a fast computerassisted interpretation using IPI2WIN [12]. The software was also used to generate geoelectric cross section of the surveyed areas.

In most geologic materials, ionic strength and control amount of pore water present majorly control the resistivity of the substratum since current is conveyed mostly by flowing ions in the pore water. High water content high ionic strength lead to lower the resistivity. Clay minerals, with their charged surfaces and associated boundary layers of attracted ions, also contribute to low resistivity [13]. Rocks conduct current by means of electrolytic and electronic conduction. The resistivity of rocks and minerals varies between $10^{-6}$ and $10^{+14} \mathrm{ohm}-\mathrm{m}$ (a range of $10^{20}$ ) when measured through its electrolytic conduction. While electronic conductivity is mainly encountered in minerals, in groundwater studies, electrolytic conductivity is most important. The conductivity is largely controlled by porosity, water content, and water quality [14].

In the VES method, the positions of the electrodes are changed with respect to a fixed point (known as the sounding point). In this way, the measured resistance values at the surface reflect the vertical distribution of resistivity values in a geological section. The VES procedure consists of passing a known amount of current (I) into the ground through two current electrodes, $C_{1}$ and $C_{2}$, and measuring the potential difference $(V)$ developed between the potential electrodes $P_{1}$ and $\mathrm{P}_{2}$. The spacing between the current electrodes is gradually increased while the distance between potential electrodes is increased only when the observed potential difference across $\mathrm{P}_{1}$ and $\mathrm{P}_{2}$ becomes quite low [15]. The electrodes $C_{1} P_{1} P_{2} C_{2}$ are placed on straight line with $C_{1} C_{2} \geq$ $1 / 5 \mathrm{P}_{1} \mathrm{P}_{2}$ the apparent resistivity for this array is given by [15].

$$
\rho_{a}=\frac{\left(C_{1} C_{2}\right)^{2}-\left(P_{1} P_{2}\right)^{2}}{4 P_{1} P_{2}}\left(\frac{\Delta V}{I}\right)
$$

Where $\rho \mathrm{a}$ is the apparent resistivity in ohm-m, $\mathrm{C}_{1} \mathrm{C}_{2}$ is the current electrode spacing in $\mathrm{m}, \mathrm{P}_{1} \mathrm{P}_{2}$ is the potential electrode spacing in $\mathrm{m}, \Delta \mathrm{V}$ is the measured potential difference in Volt, and I is the injected current in Ampere.

Schlumberger electrode configuration arrays with a maximum current electrode separation $\left(\mathrm{C}_{1} \mathrm{C}_{2}\right)$ ranging between 80 and $100 \mathrm{~m}$ were used. At every VES station, current electrodes were spread out step by step. Apparent resistivity data were calculated and manually plotted in the field for checking the data quality. If distortions or errors appeared in data, measurements were repeated or the current electrode locations were changed to improve data quality. The VES data were plotted on a log-log graph with the electrode separation $\left(\mathrm{C}_{1} \mathrm{C}_{2} / 2\right.$ or $\left.\mathrm{AB} / 2\right)$ on the abscissa and the apparent resistivity $(\rho$ a $)$ values on the ordinate. The advantages of using a log-log plot are that it emphasizes near surface resistivity variations and suppresses variations at greater depths, simply because interpretation of the results depends largely on the small variations in resistivity occurring at shallow depths.

\subsection{Geotechnical Analysis}

Nine soil samples were collected from preselected sites based on the interpretation results of the Vertical Electrical Sounding. Sampling depths were determined by the depth of the undisturbed soil using a hand auger to a maximum of $1.5 \mathrm{~m}$. samples were taken at $30 \mathrm{~cm}$ intervals. These samples were subjected to the samples include sieve analysis, Atterberg limits, natural moisture content, compaction and California bearing ratio (CBR) tests. Mechanical sieving assisted in determining particle size distribution of gravel and sand proportions of dried coarse fraction. Consistency Limit Tests 
generally known as the Atterberg limits gave the plasticity characteristics of the cohesive fraction of the sieved samples. The consistency limit test includes; liquid limit, plastic limit and linear shrinkage test. The difference between the liquid and plastic limits gave the plasticity index, which is the range of moisture contents over which the soil remains plastic.

California Bearing Ratio (CBR) test, widely used to characterize and select sub-grade materials for use in road construction was carried out. The test was devised by the California Highway Association and it is simply the ratio of the load that cause a penetration of $2.5 \mathrm{~mm}$ or $5.0 \mathrm{~mm}$ material to a standard load that causes similar penetration on a standard California sample, notably $13.24 \mathrm{kN}$ and $19.96 \mathrm{kN}$ respectively. CBR tests were carried out and swelling of samples was carefully monitored during the $96 \mathrm{~h}$ of soaking period to assess the likely effect of water ingress on the swelling of base material. The samples were compacted at the modified American Association of State Highway and Transportation Official (AASHTO) level as described under procedure for compaction test in a standard CBR mold [16].

The particular state of consistency of any particular soil depends primarily upon the amount of water present in the soil-water system thereby making the behaviour of soil directly related to the amount of water present. The Atterberg limit represents a water content at which the soil changes from one state to another. The values of the Atterberg limits of the soil samples are shown in Table 1.

Table 1. The values of the Atterberg limits of the soil samples.

\begin{tabular}{llllll}
\hline Boreholes Label & Liquid Limit (\%) & Plastic Limit (\%) & Plasticity Index (\%) & Liquidity Index & $\begin{array}{l}\text { Soil classification based } \\
\text { on the Plasticity Index }\end{array}$ \\
\hline BH1 & 12.5 & 7 & 5.5 & 2.60 & Low Plastic \\
BH2 & 13 & -0.5 & -19.06 & Non-Plastic \\
BH3 & 12.5 & 12 & -1.0 & -78.41 & Non-Plastic \\
BH4 & 11 & 9 & 5.01 & 19.91 & Low Plastic \\
BH5 & 14.01 & 14 & 1.0 & 98.98 & Low Plastic \\
\hline
\end{tabular}

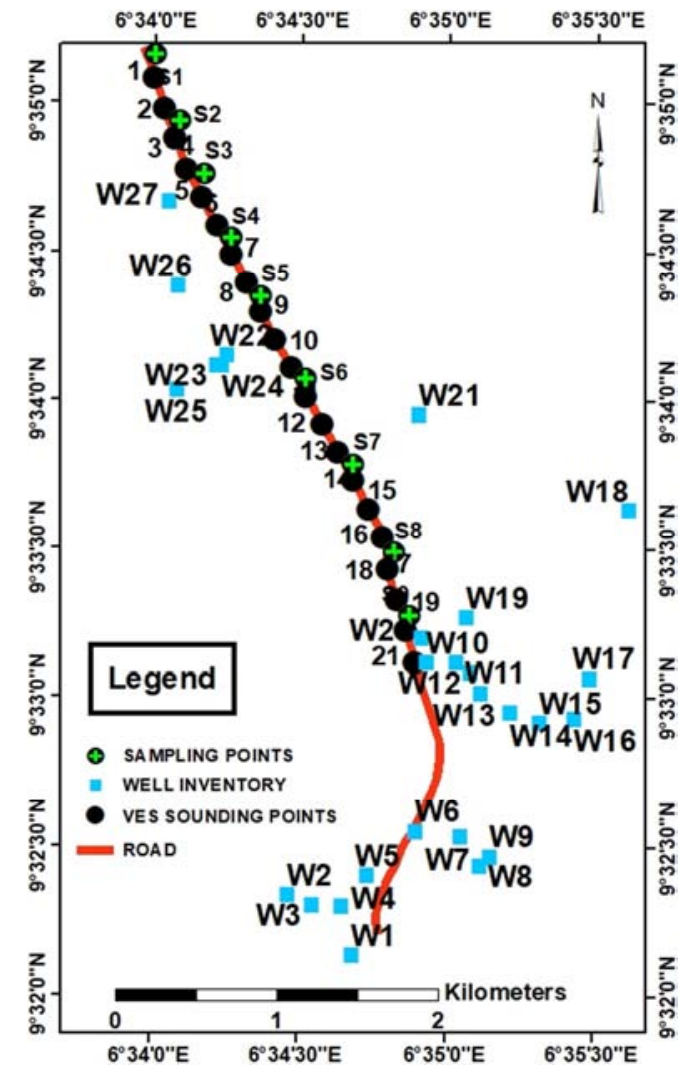

Figure 2. Map showing locations that were occupied for the Vertical Electrical Sounding (VES), soil sample collection and well inventory.

\section{Results and Discussions}

Linear structures such as fractures and shear zones that characterize the study area have different orientations. Present are the minor $\mathrm{N}-\mathrm{S}$ fractures which are attributed to brittle deformation and the twin conjugate sets of NE-SW and NW-SE trends, produced by transcurrent movements [17]. The structural framework of the Nigerian Basement Complex is dominated by the NE-SW lineaments (Figure 3).

The summary of the interpreted VES results in the study area is shown in Table 2. These data were used to produce both the resistivity and pseudo sections for the area. Four major curve types were produced from the area and these are the $\mathrm{H}, \mathrm{K}, \mathrm{KH}$ and HA curves.

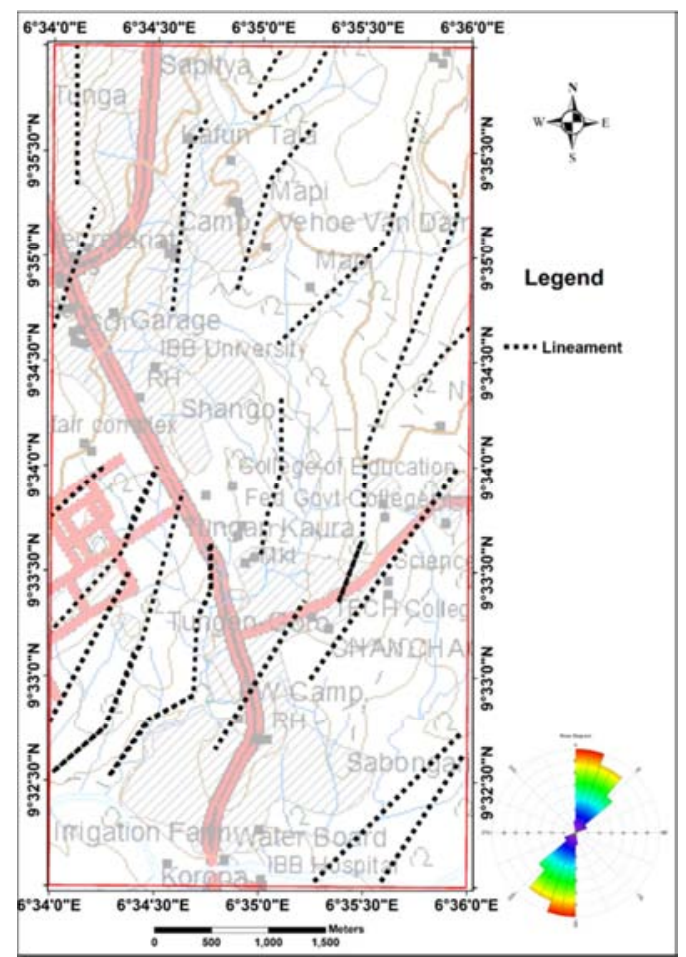

Figure 3. Lineaments extracted from Landsat 8 OLI and SRTM DEM. 
Table 2. Summary of VES data interpretation.

\begin{tabular}{|c|c|c|c|c|c|c|c|c|c|c|c|c|}
\hline \multirow{2}{*}{ S/NO. } & \multirow{2}{*}{ VES } & \multicolumn{4}{|c|}{ LAYER THICKNESS (m) } & \multicolumn{6}{|c|}{ Layer Resistivity $(\Omega \mathrm{m})$} & \multirow{2}{*}{ Curve Type } \\
\hline & & d1 & d2 & d3 & d4 & $\rho 1$ & $\rho 2$ & $\rho 3$ & $\rho 4$ & $\rho 5$ & p6 & \\
\hline 1 & 1 & 1 & 2 & 3 & & 143 & 8 & 1451 & 196 & & & HK \\
\hline 2 & 2 & 1 & 5 & & & 84 & 26 & 114 & & & & $\mathrm{H}$ \\
\hline 3 & 1 & 2 & 3 & 50 & & 32 & 56 & 8 & 59 & 818 & & $\mathrm{KH}$ \\
\hline 4 & 1 & 2 & 4 & & & 276 & 13 & 4000 & 270 & & & HK \\
\hline 5 & 1 & 2 & 3 & 12 & 25 & 28 & 45 & 12 & 140 & 34 & 2600 & HKH \\
\hline 6 & 1 & 7 & & & & 1000 & 220 & 612 & & & & $\mathrm{H}$ \\
\hline 7 & 2 & 3 & 9 & 18 & & 260 & 43 & 890 & 91 & 10000 & & $\mathrm{HKH}$ \\
\hline 8 & 1 & 2 & & & & 183 & 3 & 120 & & & & $\mathrm{H}$ \\
\hline 9 & 1 & 2 & & & & 10 & 5000 & 114 & & & & $\mathrm{~K}$ \\
\hline 10 & 1 & 2 & 4 & & & 609 & 989 & 50 & 391 & & & $\mathrm{KH}$ \\
\hline 11 & 1 & 4 & 11 & & & 231 & 31 & 15 & 41 & & & HA \\
\hline 12 & 1 & 2 & 3 & 13 & 26 & 36 & 222 & 21 & 301 & 67 & 4000 & KHA \\
\hline 13 & 1 & 3 & 15 & & & 318 & 126 & 58 & 114 & & & $\mathrm{KH}$ \\
\hline 14 & 2 & 4 & & & & 15 & 717 & 182 & & & & K \\
\hline 15 & 1 & 3 & 47 & & & 173 & 53 & 290 & 3200 & & & HA \\
\hline 16 & 1 & 2 & 3 & & & 2000 & 6 & 4000 & 60 & & & HA \\
\hline 17 & 1 & 2 & 4 & & & 426 & 1080 & 26 & 208 & & & $\mathrm{KH}$ \\
\hline 18 & 1 & 2 & 3 & & & 15 & 2000 & 39 & 387 & & & $\mathrm{KH}$ \\
\hline 19 & 1 & 2 & & & & 5 & 1000 & 30 & & & & K \\
\hline 20 & 1 & 2 & 3 & & & 139 & 292 & 17 & 187 & & & HA \\
\hline 21 & 1 & 2 & 3 & & & 150 & 312 & 15 & 220 & & & HA \\
\hline
\end{tabular}

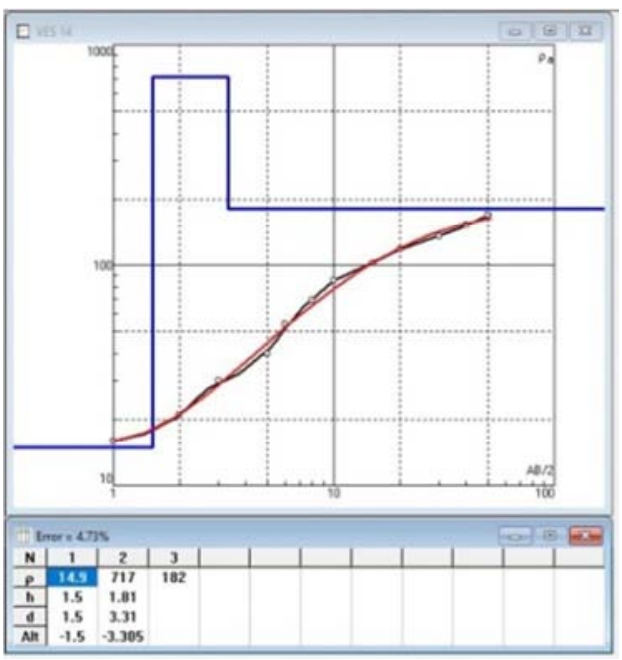

Figure 4. A K-Type curve.

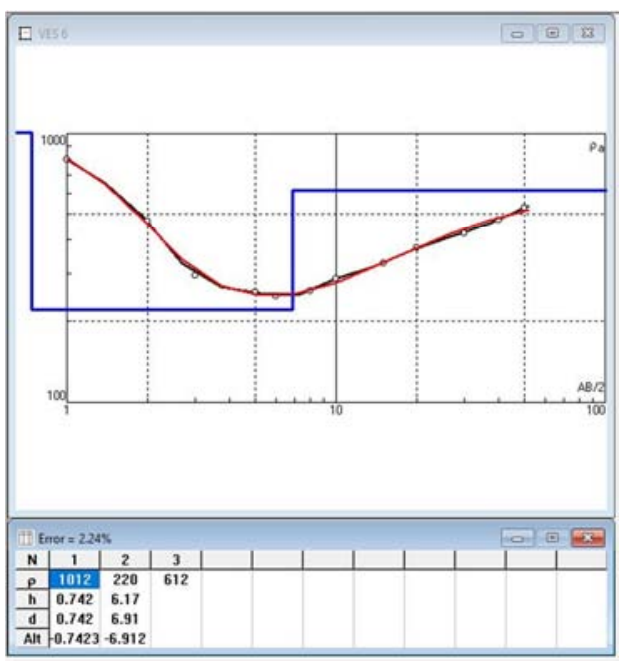

Figure 5. An H-Type curve.

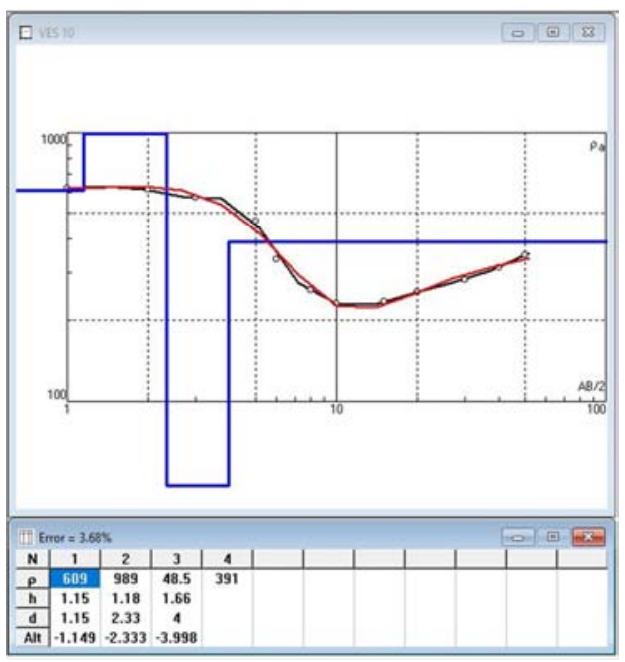

Figure 6. A KH-Type curve.

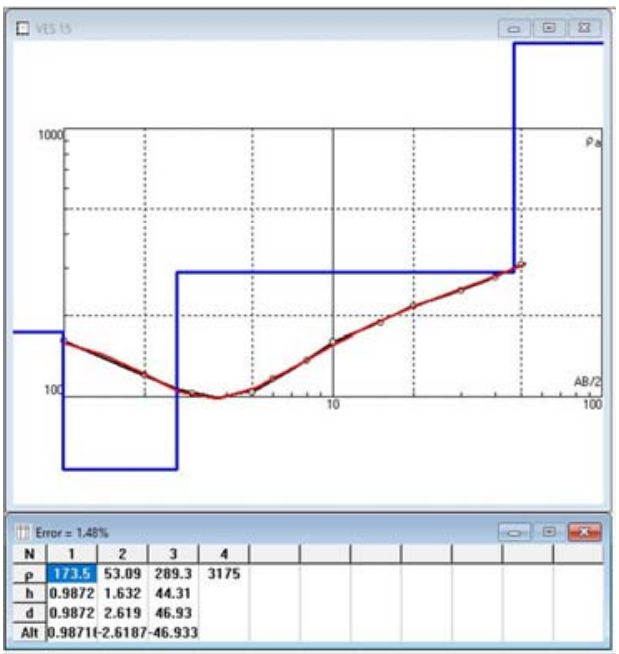

Figure 7. An HA-Type curve. 
Several inferences can be made from this. Firstly, three geoelectric layers can be observed in some places as evidenced by the $\mathrm{H}$ type curves. This means that parts of the study area is characterized by the occurrence of fresh basement at a very shallow depth as observed in the third geoelectric layer (K type curve) (Figure 4) and some parts of the investigated area have the second layer being the weathered basement layer. This scenario may increase the vulnerability of the road to failure particularly if the depth to the weathered basement layer is shallow with the evidence of water saturation in the layer $(\mathrm{H})$ as obviously shown in Figure 5. The second inference that can be made is that the $\mathrm{KH}$ curve type, wherever they occur, represents the occurrence of fractured basement as seen in the third geoelectric layer of Figure 6. The presence of fractured basement may be responsible for the failure of the road if this was not properly handled during construction. The HA curve types (Figure 7) seem ideal in these circumstances. However, it is important to take into consideration the peculiarities of the different curve types and make provision for how it may be tackled during and after the construction of the road.

The resistivity cross section shows the variations of resistivity and depth values of the subsurface layers and this would provide information on the geoelectric sequence with the penetrated depth in the study area (Figure 8). Generally, the constructed sections revealed the presence of three to four geoelectric layers. These layers are: the topsoil, the weathered layer, partly weathered/fractured basement and the fresh basement. The range of the resistivities of the top soil is highly varied with values between $5 \Omega \mathrm{m}$ to $2000 \Omega \mathrm{m}$. Thickness varies from $1 \mathrm{~m}$ to $7 \mathrm{~m}$. These resistivity values correspond to clayey sand, sandy clay, laterite to fresh rock outcropping at the surface. Top soil layers having low resistivity values $(<100 \Omega \mathrm{m})$ have the capability of undermining the stability of the road. The weathered layer beneath the topsoil is characterized by resistivity values that range between 37 and $4000 \Omega \mathrm{m}$ and their various depths vary from 1 to $47 \mathrm{~m}$. very low resistivities at such shallow depths has the potential of yielding the constructed road to failure. On the other hand, these low resistivity values may be attributed to the water saturation of these weathered zones. However, the last observed geoelectric layer of fresh basement. This basement sometimes has fractures in its upper part at some locations. The presence of fractures in this layer constitutes weak zones and brings the bearing capacity of the bedrock under question. These factors are to be seriously considered during road maintenance and rehabilitation.

Table 3 shows the summary of the geotechnical results. The Atterberg limits (liquid limits, plastic limits and plastic index) tests sought to establish and describe the consistency of the sampled soils in order to provide useful information regarding the soil strength, behaviour, stability and type and state of consolidation [18]. Liquid Limit (LL) range from $22 \%$ to $42 \%$ while Plastic Limit range from $2 \%$ to $7 \%$. Since the recommended LL for materials to be used as sub-grade and sub-base or base course materials is $\leq 35 \%$ [19], samples 7,8 and 9 failed to meet the standards. Generally, soils with high liquid limit (LL) are clays with poor engineering properties too weak in strength. Soils with intermediate plasticity index $(0$ $20 \%$ ) would make better engineering properties and thus samples 1 and 4 from the study area would make fair to good engineering materials suitable for road construction.

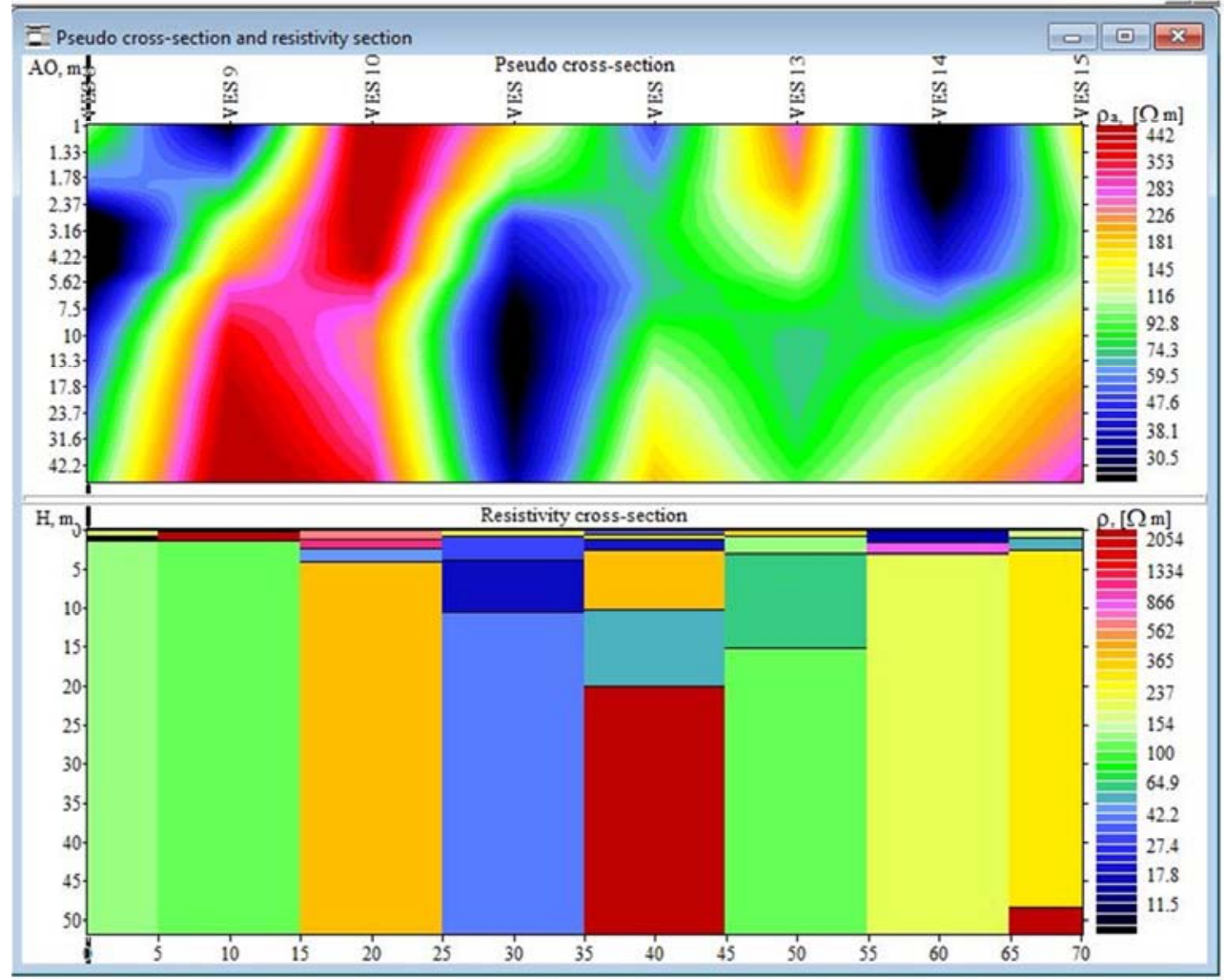

Figure 8. Pseudo and resistivity cross section of the study area. 
Table 3. Summary of Geotechnical results from the study area.

\begin{tabular}{|c|c|c|c|c|c|c|}
\hline Sample & LL (\%) & PL (\%) & PI & USSC classification & $\%$ of Soil Passing & GI \\
\hline 1 & 28.5 & 7.3 & 21.2 & $\mathrm{CL}$ & 18.5 & 0.392 \\
\hline 2 & 31 & 6.5 & 24.5 & $\mathrm{CL}$ & 29.8 & 2.146 \\
\hline 3 & 23 & 4.6 & 18.4 & CL-ML & 42.9 & 4.7636 \\
\hline 4 & 22.5 & 1.8 & 20.7 & CL & 25 & 3.07 \\
\hline 5 & 28 & 3 & 25 & $\mathrm{CL}$ & 43.6 & 6.01 \\
\hline 6 & 35 & 4 & 31 & $\mathrm{CH}$ & 38.8 & 0.76 \\
\hline 7 & 48 & 2.6 & 45.4 & $\mathrm{CH}$ & 45.5 & 2.52 \\
\hline 8 & 45 & 3.6 & 41.4 & $\mathrm{CH}$ & 42.2 & 1.62 \\
\hline 9 & 39.5 & 5 & 34.5 & $\mathrm{CH}$ & 55.5 & 4.1 \\
\hline
\end{tabular}

CL- Clay of Low Plasticity.

$\mathrm{CH}-\mathrm{Clay}$ of High Plasticity.

Correlation of the results of this study has been able to establish that the constructed road has weak zones that have relatively high water table. This is likely the reason why the sampled soils have poor engineering qualities. Also, the structural attributes of the area indicate the preponderance of shallow fractures along the pavement. This also has been attributed to compound the problem at the failed sections of the road. The degree of vulnerability along different sections of the road depends on the geophysical and geotechnical characteristics.

\section{Conclusions}

A Multi-dimensional approach to revealing causes of pavement failures in a part of North-Central Nigeria has been undertaken using Remote sensing, geotechnical studies and geophysical data. These were carried out to reveal geologic structures that may be a contributing factor to the continuous failure of the road. Also, the nature of the soils, near surface geologic sequence and their geotechnical properties were investigated to deduce the factors that have been inimical to the integrity/stability of the road.

Twenty-one (21) VES were acquired along the investigated road segment using Schlumberger array with maximum $\mathrm{AB} / 2$ separation at $50 \mathrm{~m}$. The geoelectric parameters obtained from the quantitative interpretation of VES results were used to produce the VES curves, resistivity and pseudo sections for the area. Interpreted VES curves revealed several curve types while interpreted geoelectric layers were delineated as topsoil, weathered layer, partly weathered/fractured basement and fresh basement. Most of the topsoil layers are characterized by relatively low resistivity values suggestive of weak zones that are capable of undermining the stability of the proposed road. The weathered layer beneath the topsoil is characterized by resistivity values suggestive poor engineering material and thus poses danger to the stability of the road structure. Some portions of the basement are laden with fractures that constitute weak zones capable of bringing the bearing capacity of the bedrock under question. The geotechnical results reveal that most of the investigated soil samples are clayey in nature. Integrating the results of the study has enabled the categorization of the road segment into three vulnerability zones: high, moderate and low vulnerability zones. Most of the road segment fall within the moderate vulnerability zone.

\section{References}

[1] Ighodaro, C. A. U. (2009). Transport infrastructure and economic growth in Nigeria. J. Res. National Dev. 7 (2).

[2] Ajayi, L. A. (1987). Thought on road failures in Nigeria. Nigerian Eng. 22 (1), Pp. 10-17.

[3] Momoh, L. O., Akintorinwa, O. and Olorunfemi, M. O., (2008). Geophysical investigation of highway failure - a case study from the basement complex terrain of south-western Nigeria. J. Appl. Sci. Res. 4 (6), Pp. 637-648.

[4] Oladapo, M. I., Olorunfemi, M. O. and Ojo, J. S., (2008). Geophysical investigation of road failures in the basement complex areas of south-western Nigeria. Res. J. Appl. 3 (2), Pp. 103-112.

[5] Ejepu, J. S., Olasehinde, P. I., Okhimamhe A. A. and Okunlola I. A. (2017). Investigation of Hydrogeological Structures of Paiko Region, North-Central Nigeria Using Integrated Geophysical and Remote Sensing Techniques. Geosciences 7 (4), P. 122. http://dx.doi.org/10.3390/geosciences7040122.

[6] NIMET SEASONAL RAINFALL PREDICTION (2019). Retrieved from http://nimet-srp.com/2019-Annual-RainfallPredictions.html.

[7] Sander, P. (2007). Lineaments in groundwater exploration: A review of applications and limitations. Hydrogeol. J., 15, Pp. $71-74$.

[8] Papadaki, S. E.; Mertikas, P. S. and Sarris, A. (2011). Identification of lineaments with possible structural origin using ASTER images and DEM derived products in Western Crete, Greece. EarseL eProc. 10, P. 10.

[9] Masoud, A. and Koike, K. (2006). Tectonic architecture through Landsat-7 ETM+/SRTM DEM-derived lineaments and relationship to the hydrogeologic setting in Siwa region, NW Egypt. J. Afr. Earth Sci. 2006, 45, 467-477.

[10] Kumar, T. J. R.; Dushiyantan, C.; Thiruneelakandan, B.; Suresh, R.; Raja, S. V.; Senthilkumar, M. and Karthikeyan, K. (2016). Evaluation of groundwater potential zones using electrical resistivity response and lineament pattern in Uppodai Sub Basin, Tambaraparani River, Tirunelveli District, Tamilnadu, India. J. Geol. Geophys. 5, P. 241. 
[11] Greenbaum, D. (1992). Remote Sensing Techniques for Hydrogeological Mapping in Semi-Arid Basement Terrains; Report No. MP/86/2/R; British Geological Survey: Nottingham, UK, 1992.

[12] Bobatchev, A., Modin, I. and Shevnin, V. (2001). IPI2WIN v. 2.0, User's manual.

[13] Singh, S. B., Veeraiah, B., Dhar, R. L., Prakash, B. A. and Rani, M. T. (2011). "Deep resistivity sounding studies for probing deep fresh aquifers in the coastal area of Orissa, India," Hydrogeology Journal, vol. 19 (2), pp. 355-366.

[14] Patra, H. P., Adhikari, S. K. and Kunar, S. (2016). Groundwater Prospecting and Management, Springer Hydrogeology.

[15] Zohdy, A. A. R., Eaton, G. P. and Mabey, D. R. (1974). "Application of surface geophysics to ground-water investigations," in Techniques of Water-Resources Investigations of the U.S. Geological Survey, Book 2, chapter 1.
[16] Osinowo, O. Olawale, Akanji, A. Olusoji, and Akinmosin, Adewale (2011). Integrated geophysical and geotechnical investigation of the failed portion of a road in basement complex Terrain, Southwest Nigeria. Mater. Geoenviron. 58 (2), Pp. 143-162.

[17] Ejepu, S. J., Adebowale, T. A, Abdullahi, D. S., Yusuf, A. and Ochimana, K. (2014). Subsurface Structural Mapping for Groundwater Resource Development of a Part of TudunFulani North- Central Nigeria Using Radial Vertical Electrical Sounding Technique. International Journal of Engineering Sciences \& Research Technology. ISSN: 2277-9655. Http://www.ijesrt.com.

[18] Mallo, S. J. and Akuboh, I. N. (2012). Geotechnical investigation of soils: a case study of Gombe town (Sheet 152NW), North Eastern Nigeria. Int. J. Modern Eng. Res. (IJMER) 2, 4280-4286.

[19] Nigerian Federal Ministry of Works and Housing (1997). General specification for Roads and Bridges. Federal Highway Department. 